Talented Suppliers? Strategic Change in the UK Aerospace Industry and its Implications for Innovation

David J. Smith

Nottingham Trent University
David Tranfield

Cranfield School of Management, UK

Address for Correspondence:

Professor David J. Smith

Nottingham Business School

Nottingham Trent University

Burton Street

Nottingham

NG1 4BU

UK

Tel. $\quad 00441158484745$

Fax. 00441158486512

Email David.Smith02@ntu.ac.uk 
TALENTED SUPPLIERS? STRATEGIC CHANGE IN THE UK AEROSPACE INDUSTRY AND ITS IMPLICATIONS FOR INNOVATION

\begin{abstract}
The 1990s marked the start of extensive re-structuring in the aerospace industry throughout the world. While the ensuing consolidation among prime contractors has been widely researched, the changes affecting the aerospace supply chain have received less attention. This study focuses on the re-structuring taking place within the supply chain of the UK aerospace industry. The findings point to extensive restructuring. Unlike most earlier studies the lean supply model was found to be a powerful influence, with suppliers moving away from subcontractor status and instead taking on the mantle of 'talented' suppliers. While some of the implications of lean supply, in terms of the dynamics of innovation, were not apparent, there were modest signs of increased process innovation on the part of some suppliers.
\end{abstract}




\section{TALENTED SUPPLIERS? STRATEGIC CHANGE IN THE UK AEROSPACE INDUSTRY AND ITS IMPLICATIONS FOR INNOVATION}

\section{INTRODUCTION}

The aerospace industry in the UK and elsewhere is in the throes of change. This is linked to greatly increased competitive pressures affecting firms across the industry. Where in the past competition was based around differentiation and technical features, over the last decade issues of cost and affordability have come to the fore.

Significantly the increased competitiveness and emphasis on cost leadership has not been confined to the civil sector, the same pressures are now much in evidence in the defence sector.

In the civil sector, commercial airlines have become more cost conscious in the face of the twin forces of de-regulation and privatization. The de-regulation that transformed the airline industry in the US in the 1980s (Sampson, 1984), has now spread across the world (Hanlon, 1999). The growth of 'no frills' airlines in the US and Europe (Dogannis, 2001) is only one sign of a much bigger change in the commercial environment. The effect of de-regulation combined with the privatization of many state-owned airlines has been to heighten competition among the world's airlines ending the 'built-in incentives and premiums for innovation' and instead substituting greater pressure for cost reductions (Gray, Golob and Markusen 1996: p657), not just in the short run but in the long run too. This in turn has impacted on the commercial sector of the aerospace industry making issues of cost and affordability much more important.

The defence sector has faced the twin forces of reduced defence spending, following the ending of the Cold War (Bilstein, 2001, Moore et al. 2001) and tougher procurement regimes (Owen, 1999). Defence cuts led to reductions in orders for new aircraft and a greater willingness to extend the service life of existing aircraft. Procurement changes arose from concerns in both the US (Patillo, 1998) and the UK with cost over-runs. In the UK the biggest change was a move away from the cost plus environment of the 1960s and 1970s where defence contracts were awarded by the state on a non-competitive basis and priced according to actual cost plus a profit mark-up (Bishop and Williams, 1997: p21), in favour of a regime of competitive tendering and fixed price contracts. These changes marked an end to what Bishop and Williams (1997: p21) describe as, 'the cosy relationship between management, the military and the state', where firms could maintain their position in the industry through producing highly specialised products. In its place came a much greater emphasis on costs. In this environment not only was outright cost important, so too was cost of ownership, and the profitability of defence suppliers was directly linked to the effective control of costs.

Faced with increased emphasis on affordability and costs in both the civil and defence sectors, the aerospace industry responded by re-structuring, that saw rationalization and shakeout (Heppenheimer, 1995), as firms merged or left the industry altogether (Hayward, 1994). Most evident in the US in the early 1990s, a similar pattern was much in evidence in Europe later in the decade (Moore et al., 2001). More recently the shock waves of change leading to a more competitive, price sensitive environment 
have begun to ripple through the supply chain, as prime contractors have sought to improve their competitiveness by making the supply chain more efficient.

It is these changes that form the focus of this study. It aims to identify the strategic changes currently taking place in the aerospace supply chain in the UK and to analyse the impact of these changes upon suppliers, especially the role of suppliers within the supply chain. In the process the study endeavours to assess the implications of suppliers's new role for innovation within the UK aerospace industry.

\section{LITERATURE REVIEW}

The aerospace supply chain has received much less attention from researchers than its automotive counterpart. Nonetheless the small number of studies that have been undertaken in the US and Europe, indicate that the 1990s saw the start of a process of strategic change involving extensive re-structuring of the supply side of the industry, a process that is still underway. The studies fall into two broad categories. There are those that provide a broad overview of the current trends with few references to specific examples and there are the more specialized studies that examine the changes taking place in the aerospace supply chain through case studies of particular organizations, including both prime contractors and suppliers.

Examples of studies that fall within the first category include Paliwoda and Bonaccorsi (1994) and Moore, Neal and Antill (2001). Paliwoda and Bonaccorsi's study focuses on trends in procurement within the European aircraft sector. Given the focus, the study not unsurprisingly deals mainly with aspects of procurement. However it does identify a number of broad trends within the aerospace supply chain. These include prime contractors reducing the size of their supplier base and the introduction long term agreements with their suppliers. The trend towards prime contractors reducing their supplier base, through a process of supplier rationalization that means they purchase directly from fewer first tier suppliers, was also picked up by Moore, Neal and Antill (2001). Another feature noted by both studies was the trend towards the involvement of suppliers in the early stages of new projects. Alongside these changes Paliwoda and Bonaccorsi (1994, p236) also noted a move towards 'systems buying' that is prime contractors purchasing complete systems or sub-systems as modules rather than purchasing individual components and undertaking assembly of the system themselves.

While these studies suggest that aerospace is following the automotive industry in terms of the nature of the strategic changes taking place in the supply chain, they are short on specific examples of practice. Fortunately a small number of recent research studies, involving case studies of specific organizations, have begun to furnish more details. What makes these studies particularly useful is that the case studies are drawn from both sides of the supply chain and both sides of the Atlantic, involving prime contractors and suppliers, as well as US and European aerospace companies. 
Bozdogan, Deyst, Hoult and Lucas (1998) in a study of two US prime contractors not only concur with the trends identified in the more broadly based studies, including the introduction of long term agreements, they also highlight changes in the nature of the relationship between prime contractors and their suppliers. They note a move away from conventional sub-contracting in favour of closer more collaborative relations, characterised by trust-based relationships that emphasize a team approach. They also found evidence of suppliers enhancing the range of capabilities they have to offer their customers..

Frear and Metcalf (1995) undertook another US based study that also featured indepth case studies, this time of a single organisation, a supplier manufacturing complex aluminium and magnesium castings for aero engines. Within the supply chain the relationship between prime contractor and first tier supplier had recently changed. Frear and Metcalf (1995) found that the first tier supplier had taken over responsibility for a major engine subsystem or module, namely the engine gearbox. In turn the relationship between the gearbox supplier and the castings manufacturer had also changed. The relationship was now more collaborative with the castings manufacturer providing extensive technical support. What emerges is a picture of increased specialisation as the castings manufacturer extended its competence and capability within its chosen field.

The three European studies were drawn from three different countries, Sweden (Brown, 2000), France (Talbot, 2000) and Italy (Giunta, 2000). The Swedish study involved a case study of Volvo Aero based in Trollhättan, a first tier supplier that makes commercial aero engine parts for the 'Big Three' commercial aero engine manufacturers General Electric, Pratt and Whitney and Rolls-Royce, as well manufacturing and servicing military engines. Although the study focussed principally on barriers to local sourcing, it provides a valuable perspective on developments in the aerospace supply chain. As the scale of its commercial aero engine work has grown so the company's role has changed (Brown, 2000, p298). It is increasingly focusing on its core business. As a result Volvo Aero is becoming less vertically integrated, outsourcing ancillary services, including metal fabrication, to small local suppliers. However as Brown (2000, p299) shows this has been associated with extensive supplier development work on the part of Volvo Aero, including the provision of training, technical assistance and the sale of specialized capital equipment, in order to help upgrade the all-round capability of its suppliers.

In contrast Talbot's (2000) study focuses not on a supplier, but on a prime contractor, the French aerospace manufacturer Aerospatiale. The study looks at the changes that have occurred in Aerospatiale's subcontracting relationships particularly in terms of its suppliers in the Midi-Pyrenees region around Toulouse in the South West of France. Like the earlier studies it notes that during the 1990s, Aerospatiale, as a prime contractor rationalized its supplier base, with important consequences for the surrounding region (Talbot, 2000, p213). Although Talbot (2000) suggests that one of the primary reasons for this was a decline in state support for Aerospatiale, he notes that it was also accompanied by changes in the company's relationship with its suppliers. In particular the development of closer relations with suppliers involving 
monthly programme reviews and the use of electronic communication for scheduling orders and deliveries.

Finally Giunta (2000) explored the changes taking place during the 1990s in the Italian aerospace industry, focusing on the first tier supplier, Alenia, and its associated network of suppliers based in the Campania region of Southern Italy. Alenia manufactures aerostructures, which take the form of major airframe sub-assemblies including fuselage sections, vertical stabilizers and flaps. Alenia is a direct supplier to the main commercial airliner producers Boeing and Airbus. Giunta (2000) found that as far as Alenia was concerned, while there had been extensive restructuring of the supply chain in the more difficult trading environment of the 1990s, extending to continued vertical disintegration and rationalization of the supplier base in Southern Italy, there was only limited evidence of systems buying or collaborative relationships.

These studies show that the aerospace industry has been subjected to extensive restructuring during the 1990s. In particular there have been majors changes taking place as far as the supply chain is concerned. The case study based research in particular highlights the fact the change has not been confined to one part of the supply chain, for instance the prime contractors. Rather strategic changes have been affected suppliers at all levels. The three European studies also highlight that the changes have not been confined to one side of the Atlantic. Despite the lack of a major study based on the UK aerospace industry, it is clear that strategic change and restructuring have occured in Europe as well as the US.

What has been behind the changes? Nearly all the studies point to the less favourable environment for aerospace that resulted from the ending of the Cold War combined with the global recession of the early 1990s. This fits with the picture outlined at the start of the paper. What is perhaps more surprising is that only one study, that by Giunta (2000, p39), really takes this any further and suggests that the new competitive environment has led to the adoption of a new approach to manufacturing and procurement. The approach takes the form of what has come to be known generically as lean production.

The lean production model as outlined in the seminal work of Womack et al. (1990) describes the manufacturing and procurement techniques introduced into the automotive industry by the Japanese. Lean production represents a new mode of production (Saunders, 1997, p16) capable of transforming manufacturing activities in the same way that mass production did in the early years of the 20th century. Lean production is associated with the elimination of all forms of waste including superfluous procedures (Lamming, 1996, p196) from all stages of the production process ranging from the procurement of raw materials through to the end consumer (Lamming, 1996: p184). From the outset the role of the supply chain has been an important element in the lean production model. One of the first accounts of lean production (Krafcik, 1988: p43) noted that supply chain arrangements were different, in particular that vertical integration was largely absent and that instead external suppliers were closely integrated into assembly operations. Similarly Kay (1993) 
comments that relationships with suppliers can be a an important aspect of an organisation's 'distinctive capability'.

The importance of the supply chain within lean production has led to the emergence of lean supply, that is, the establishment of arrangements within the supply chain designed to aid and facilitate lean production methods. In lean supply, 'the entire flow from raw materials to consumer' is considered as an integrated whole (Lamming, 1996: p187) and managed so as to minimize waste in all its forms. According to Lamming the fundamental principle of lean supply is that, 'the effects of costs associated with less than perfect execution of a sub-process are not limited to the location of the execution'.

For firms previously wedded to vertical integration, lean supply is a significant change. Even for firms, such as aerospace prime contractors, who have in the past made extensive use of sub-contracting, lean supply means strategic changes in terms of relations with the subcontractors who make up their supply chain. Whereas in the past subcontracting may have been a means of overcoming capacity constraints (Freeman, 1991: p505, Sako, 1994, p269), lean supply involves closer relationships between prime contractors and their suppliers with much effort directed at the management of such relationships. Unlike supply chain management neither party in such relationships is dominant, one of the differentiating principles of lean supply is that both parties recognize the 'mutual destiny' of their neighbours in the supply chain (Lamming, 1996: p187).

In his work on lean supply, Lamming highlights the changing role of suppliers. Under lean supply, suppliers need to possess a range of capabilities and behave in a way that makes them more than mere subcontractors. First tier suppliers especially, who are close to the final industrial customer, take on a strategic role. These strategic suppliers Lamming (1993: p180) describes as 'talented' suppliers.

What makes some suppliers within the supply chain strategic suppliers and thereby merit the title of talented suppliers? Lamming suggests that these strategic suppliers are differentiated by a number of characteristics. These can be grouped under three main headings. Firstly they are larger suppliers, with an increased range of enhanced capabilities. Consequently they can offer a broader range of services. Their greater capability means they are also able to play a bigger developmental role within the industry.

Secondly strategic suppliers can be differentiated by their place in the supply chain. As prime contractors, in pursuit of lower costs, increasingly prefer to purchase fullyassembled sub-systems or modules, so they increasingly delegate part of the integration task to their suppliers. Thus strategic suppliers integrate diverse technologies into the sub-system for which they are responsible. This responsibility combined with their position as a direct supplier to prime contractors serves to differentiate them from other suppliers from lower tiers who merely supply components or sub-contract services. In practice this is also likely to mean that strategic suppliers have responsibility for coordinating and managing their own suppliers and sub-contractors from lower tiers of the supply chain (Lamming, 1993: p189). The extent to which strategic suppliers are differentiated in this way is closely linked to the development of systems within the final product. It is the development of 
systems that facilitates this form of tiering. With responsibility not just for manufacture, but design and development as well, strategic suppliers effectively become systems integrators for the system or module for which they are responsible.

The third feature of strategic suppliers is the presence of a strong vertical relationship with their customers. What makes the relationship strong? It is a long term relationship (Syson, 1989, p17; Lamming, 1996, p196) rather than one based on short term 'dog eat dog' relations (Lamming, 1996, p185) that are associated with competitive bidding. The long term nature of the relationship is reflected in the use of formal long term agreements (Giunta, 2000, p40) between customer and supplier.

Another feature of the relationship is that it is based on collaborative effort rather than competition. Collaboration typically involves the sharing of information in contrast to the adversarial approach that characterizes traditional procurement arrangements. Strong vertical relationships are also according to Lamming (1993, p178) ones between equals, that do not recognize the traditional stance of suppliers in relation to customers. Equality stems from the recognition by customers and suppliers that they are in 'the same boat', with their mutual destinies closely linked (Lamming,1996, p187). This is a far cry from the traditional 'arm's length' purely contractual relationship (Syson, 1992: p93) typical of procurement regimes in many industries, even in the 1990s, including aerospace (Gray, Golob and Markusen, 1996: p657).

While lean supply is clearly concerned with the elimination of activities that are wasteful and inefficient it also has implications for innovation. Lamming, (1993, p195) suggests that lean supply is not just about the elimination of waste in order to lower costs and improve efficiency. Lamming (1993) suggests that a move towards lean supply may have implications as far as innovation is concerned. The context of Lamming's consideration of lean supply is the automotive industry and he observes that in this industry the standardisation and vertical integration associated with mass production may well have discouraged innovation especially where suppliers are concerned. Moves towards lean supply he suggests may provide scope for changing the dynamics of innovation as vertical disintegration releases the innovative capability of suppliers. Other researchers (Saunders, 1997; Sako, 1994) have lent support to this view. Sako (1994: p270) for instance suggests that suppliers are more likely to innovate if they think they will get a share of the benefits.

This perspective contrasts sharply with the much more pessimistic perspective of Bruce and Moger (1999). Bruce and Moger (1999) suggest that initiatives like lean supply and supply chain management may actually have the opposite effect. The substance of their case is that close relationships between supplier and customer may limit a supplier's absorptive capacity (Cohen and Levinthal, 1990) so that it fails to absorb and utilize the external stimuli that should lead to innovation. They suggest (Bruce and Moger, 1999: p122) that under lean supply firms may be, 'concentrating so hard on their joint realities' that they miss or fail to appreciate technological opportunities that emerge in the marketplace.

Against this background the adoption of lean supply is likely to have important consequences for a high technology industry such as aerospace. Indeed the implications of lean supply for innovation are a source of particular interest. 


\section{METHODOLOGY}

Since the aerospace industry has not been the subject of a great deal of scholarly attention, the study reported here should be seen as indicative and exploratory. The aim is to identify the changes taking place and to try to make sense of them. The research approach was qualitative and as such designed to illuminate the issues (Gillham, 2000) surrounding strategic change in the UK aerospace industry and provide insights into the processes at work.

The investigation comprised two parts. The first part explored the character of the changes taking place in the UK aerospace industry. This was undertaken through the analysis of specialist literature and interviews with 'key informants'. The specialist literature comprises a variety of weekly and monthly magazines on the industry, together with a small number of annual industry reviews published by trade associations and books about the industry. These publications provide extensive background detail. The annual reports of aerospace manufacturers at different levels of the supply chain were also reviewed. In addition, key informant interviews were undertaken with three individuals, each of whom had close links to the aerospace industry.

The second part of the study involved in-depth interviews with executives and managers working for companies from across the aerospace industry supply chain. A total of ten semi-structured interviews were undertaken. The interviewees included four managing directors and one company chairman. One interviewee was a consultant who worked exclusively for aerospace organizations. The remaining interviewees were functional managers. Although the number of interviews was small, the fact that sample included a large proportion of senior managers able to comment in detail on industry trends was felt to be significant. Each interview lasted 1-2 hours and was taped. The tapes were subsequently transcribed with outstanding points then clarified with respondents over the telephone. Field notes were also made. A 'purposive' sampling approach (Saunders, Lewis and Thornhill, 2003) was used in selecting the sample, in order to include interviewees well placed to comment on changes taking place within the UK aerospace industry. The sample included individuals from some of the major players in the industry but also covered companies from other levels of the aerospace supply chain. The data was analysed manually, which was manageable given the small number of interviews. Data reduction, designed to sharpen and focus the data, was undertaken by coding the transcripts and field notes. Coding facilitated sorting into clusters based on emerging themes, such as partnership relationships. In addition a small number of 'vignettes' (Miles and Huberman, 1994: p51) were identified that succinctly and graphically illustrated the changes taking place in the industry. 


\section{THE UK AEROSPACE INDUSTRY}

Though dwarfed by its American counterpart, the UK aerospace industry is the second largest in the Western world and the largest in Europe. In 2000 it achieved a turnover of $£ 18.49$ billion (SBAC, 2002) and employed 147,090 employees. These figures mark its importance to the UK economy. Aerospace contributed 2.2 per cent of the UK's Gross Domestic Product (Francillon, 1998). At the same time 63 per cent of the industry's output was exported. Contributing $£ 2.8$ billion to the UK Balance of Trade. The UK aerospace industry's return on capital was higher than either the European or American average. The industry has generally adapted well to the new environment. It is now much less dependent on the state. Whereas the military/civil split of sales was 70:30 in 1980 by the mid-1990s the split was 54:46 (House of Commons, 1993).

In terms of structure, the aerospace industry comprises three sectors: airframes and systems, engines and equipment. Some idea of the relative importance of each sector can be gauged from the numbers employed. Not unsurprisingly airframes and systems is the biggest sector employing $42 \%$ of the industry workforce. It is made up of a small number of large prime contractors like BAE Systems that manufacture aircraft, helicopters, missiles and satellites. As prime contractors they are systems integrators who design, develop, manufacture and support the final product. As systems integrators they possess the full range of capabilities and have ultimate control of the product. The engine sector is much smaller with 24 per cent of industry employment. It is dominated by a single prime contractor, the engine manufacturer Rolls-Royce.

The equipment sector forms the bulk of the supply chain. It comprises firms making a 'plethora of parts and components which go into finished aircraft' (Todd and Simpson, 1986: p111). In terms of products it includes aircraft instruments, avionics, communications equipment, computer systems, gears and transmissions, landing gear and navigation systems. As part of the supply chain, equipment manufacturers supply the prime contractors. The supply chain is pyramidal in structure, with a small number of large prime contractors supplied by a 'comet's tail' (Hayward, 1994: p6) comprising a large number of generally small equipment suppliers. The equipment sector accounts for 34 per cent of those employed in the UK aerospace industry. However this figure is deceptive and understates the scale of the aerospace industry supply chain. It includes a handful of larger suppliers like Smiths, Cobham and Meggitt which though smaller than prime contractors like BAE Systems, nonetheless are large enough to be classified among the world's 100 largest aerospace companies. However many suppliers are not included in the industry's total employment. They supply other industries such as the automotive industry and are not classified as aerospace companies. Moore et al. (2001: p39) estimate that small and medium sized enterprises (SMEs) constitute, 'the bulk of the industry in terms of revenue and employment'.

It is the large number of small equipment suppliers that helps to give the industry its distinctive pyramid structure. At the top of the pyramid are the prime contractors, 
who, as systems integrators have overall responsibility for programmes and a full range of design, development and manufacturing capabilities. Underneath are a very large number of suppliers. Many are small enterprises supplying specialized components and services. Moore et al. (2001) note that information has traditionally flowed down from the systems integrators to suppliers who have acted as subcontractors, a relationship usually described as arm's length contracting.

\section{STRATEGIC CHANGE IN THE UK AEROSPACE INDUSTRY}

Aerospace is widely recognized as a high technology industry. By its very nature is a high precision, high quality, high performance industry whose products Hobday (1998: p689) classifies as complex products and systems (CoPS). Manufacturing is carried out on the basis of small batch production methods. It is more akin to motorsport as an industry than the automotive industry. Consequently as one recent study (Hislop, 1997) put it, as late as the early 1990s the UK aerospace industry was dominated in managerial terms by projects controlled by engineering functions, with the technical aspects of projects being given precedence over other issues, especially commercial ones. As far as the supply chain was concerned, the dominant relationship was one in which, as one of the respondents in our study described it, 'the subcontractor cuts metal'. Another respondent summarized the situation when he observed that, 'aerospace is a very staid industry'.

However evidence from both documentary sources and the interviews conducted as part of the study clearly points to what can only be described as strategic changes sweeping through the aerospace industry in recent years. One key informant reflected that, 'the game is definitely changing'. The managing director of one medium-sized aerospace subcontractor talked of, 'an industry in turmoil' while the managing director of a much larger aerospace supplier described his organization as, 'bracing itself for further upheaval'. In fact all the respondents talked about strategic changes underway within the industry.

What kinds of change? There were frequent references to re-structuring by means of company acquisitions and disposals. One of the key informants described how a large first tier supplier had been 'acquiring heavily in the US', while another described recent changes in the industry as, 'all about integrating and bringing businesses together'. In fact every one of the companies from whom respondents were drawn had been involved in acquisitions or disposals within the last five years. In two instances venture capitalist organizations had been behind the re-structuring, buying subsidiary companies from large organizations and then merging them with other companies. These acquisitions were not, as one respondent put it, 'acquisitions for the sake of bulk', they were targeted acquisitions designed to add to the range of expertise that the acquiring organization was able to offer as an aerospace supplier.

Nor was the re-structuring confined to acquisitions. One respondent, the managing director of a first tier supplier, noted how his organization had acquired several companies in the last 10 years. In each instance the company's intention was to, 'buy it for a specific purpose'. However where the business contained peripheral activities 
that did not fit the company's strategy, the company would, 'package them up and sell them to the highest bidder'.

Another strategic change highlighted by a large proportion of respondents was a trend towards vertical disintegration and increased use of outsourcing. One respondent, the chairman of a first tier supplier, suggested that within the aerospace industry, outsourcing was not new. Many prime contractors were originally highly vertically integrated not out of choice but because the highly specialized nature of much of the materials and processes they employed, meant that there simply was no one else to manufacture the very large number of parts and components they required.

Outsourcing, he suggested, often began with prime contractors seeking additional capacity to cope with the highly cyclical nature of the aerospace industry. As the subcontractor accumulated expertise, outsourcing became permanent. He added that more recently prime contractors had taken renewed interest in outsourcing,

'they are looking at what they do and coming to the conclusion that their business is not making parts their business is technology and designing and selling engines. If parts can be obtained from specialists, why spend large amounts of money owning factories and the people who sit in those factories.'

However several respondents indicated that the trend towards increased use of outsourcing had been gathering momentum during the 1990s. One respondent detailed what happened to the aerospace supplier he was working for in the early1990s,

'We had a strategic outsourcing initiative from 1992 onwards. We used to fabricate most parts ourselves. We had a huge outsourcing initiative predominantly driven by lack of finance to develop new programmes. A lot of our employees went to local suppliers, machine shops and tooling manufacturing companies. Where we performed these services ourselves we outsourced them and people who were laid off or wanted to leave the company, went to work for these smaller organizations.'

This vignette (Miles and Huberman, 1994: p81) was not an isolated case. Another responded recounted how,

'the joke in the industry was that the builders, British Aerospace, Shorts and Boeing had an ambition, which was to buy an aircraft in two halves, to add the last two bolts, to bolt it together, to spray it and roll it out.'

Hence as the product has become more complex with more technologies being employed, prime contractors have become increasingly concerned to focus on their core activities, making outsourcing an increasingly attractive option. Alongside this broad trend towards outsourcing and vertical disintegration one can also discern a trend towards the outsourcing of specific functions. One respondent for instance described how in the late 1980s his organization, as a subcontractor had, 'all of the quality assurance process including the final check' handed down to it by the prime contractor. Nor was this the end of the story. The same respondent went on to note, 
'so by the beginning of the 1990s we were in supplier mode. We ran our own quality assurance completely, including the final signing off. We finished, we treated components and we delivered systems.'

\section{THE ROLE OF SUPPLIERS}

As well as these broad industry-wide trends that have had a wide-ranging impact on the aerospace supply chain, the interviews with practitioners carried out as part of the study unearthed more specific changes that point to the same suppliers increasingly taking on a new role, that owes less to the traditional subcontractor role associated with suppliers in the aerospace supply chain and instead closely follows that described by Lamming (1993) in putting forward the notion of 'talented suppliers', which he argues is a feature of lean supply.

Larger and more capable suppliers

A movement towards larger suppliers appeared to be associated with prime contractors rationalizing their supplier base. Three quarters of respondents, identified a clearly discernible trend towards rationalization the size of the supply base, so that prime contractors interface directly with fewer suppliers. Whereas in the past prime contractors procured components from thousands of suppliers, increasingly in both the airframe and engine sectors, they now deal directly with far fewer. Hislop (1997) refers to British Aerospace in the mid-1990s reducing the size of its supply base from 11,000 to 4,000 firms. However most respondents pointed to rather more dramatic reductions. As one respondent explained,

'...prime contractors like Rolls, their strategy has been to reduce their upplier base from five hundred to fifty key suppliers.'

The logic behind the change is simplifying practice and increasing efficiency. Hislop (1997: p6) notes that prime contractors in the past maintained 'large administration, quality and contract departments, in order to ...control the large amount of subcontract work.' Thus working with fewer suppliers, especially where they are designated preferred suppliers, reduces the need for this sort of administrative work and the departments and staff associated with it.

As the number of suppliers is reduced, so those that remain get bigger and extend their capabilities. For instance, one respondent described how the organization for which he worked, had only recently been formed, by merging three formerly separate companies. He explained how,

" $X Y Z$ is a relatively new company formed about 18 months ago. It was formerly three separate companies $X$ at Oldbury, $Y$ at Birmingham and $Z$ at Redditch. These were all medium-sized engineering companies, which supplied the aerospace industry."

The same respondent went on to stress, 
"More and more we're expected to work closely with our customers. The bigger suppliers they've got the resources to support this sort of thing. Size is important."

Another respondent noted the part played by venture capitalists in creating larger and more capable suppliers,

"The more enterprising venture capitalist will look not just to buy a four hundred million pound company, but will be looking for that company to be a vehicle for strapping on things that the company itself couldn't afford. So with venture capitalist money companies can make acquisitions that will build the supplier and double its size."

The logic behind suppliers being bigger is that they are more capable and able to offer a broader range of services. Extending the range of services that a supplier could offer to prime contractors was an aim for all the subcontractors interviewed. One explained his company's policy in terms of,

"the aim was to provide a unique service where you would go from billet to forging to machining to surface treatment. It was a case of consolidation but very much with the idea of providing a one-stop-shop service."

The impact of increasing the range of services offered, in terms of the role of the supplier, was illustrated by another respondent,

"So the role of the subcontractor, and we were one, was to move progressively towards being a tier one supplier rather than just a subcontract metal cutter. In our case we decided that we would extend our metal cutting by adding a composite material manufacturing capability."

Nor was this an enhancement of an organisation's capabilities simply a matter of being able to provide a broader range of services. The earlier reference to a firm being able to offer a 'one-stop-shop' type of service indicates that suppliers were now offering a different kind of service to their customers. Similarly some respondents talked of extending their product range. One respondent described how his organization had extended its product portfolio,

"We saw that there was a big business opportunity coming in industrial turbines and not only was that for airfoils but it was for a different process. Instead of forging it was a casting process, investment casting, and $X$ had very little casting capability. So the acquisition of $Y$ was made which automatically gave us investment casting facilities to support the industrial turbine business.

Hence what emerges is a picture of suppliers both large and small extending their capabilities. For the smaller suppliers this amounts to offering more services while for the larger suppliers it is also about extending the range of products they supply.

\section{Differentiated into tiers}

Tiers are not new to the aerospace industry since it has long been recognized that the industry is pyramid-shaped, with prime contractors on top of a large number of 
suppliers who are essentially subcontractors. This structure remains under lean supply but the function of suppliers changes. Instead of just being subcontractors, some suppliers at least are differentiated as they increasingly take responsibility for complete sub-systems integrating several components into a sub-system that they then supply to the prime contractor (Lamming, 1996). In the process these first tier suppliers effectively become systems integrators themselves co-ordinating and managing their own supplier base. Components produced by firms within this supply base are routed through first tier suppliers (Lamming, 1996: p190). Hence tiers of the supply pyramid are increasingly differentiated. These suppliers, usually designated preferred suppliers, that remain as first tier suppliers take on a more extensive range of functions to enable them to deal direct with prime contractors, while the remainder supply components.

Several respondents talked about their organization now assuming responsibility for complete sub-systems. A respondent from one of the larger suppliers offered a vignette that showed this process at work,

"A. recently bought a company called $B$. They subsequently bought a company in Lincoln called C., that's part of a very clear strategy to move into modular supply, in that C. and B. are two of the three companies in the world that can make compressor turbine discs and to a certain extent shafts. We can see the idea that they are going down the road of being able, at some stage, to supply a complete rotating assembly."

Nor was this confined to relatively large items. Another respondent from a company that had been a pure subcontractor producing small components explained how they too had been encouraged to engage in modular supply,

"Suppliers were encouraged to take a more integrated approach so that components were cut and then finished and treated by the supplier. Subassemblies were carried out, things like bearings were fitted, units were put together and complete sub-assemblies of a working nature were then sold to the customer."

Previously only prime contractors managed and coordinated suppliers. However one of the expert witnesses noted that 'prime contractors like R. want first tier suppliers to manage other suppliers for them', and this was borne out in the interviews with practitioners. Several of the respondents who were employed by suppliers indicated that coordinating their own suppliers was a task that they were taking on if they wanted to be so-called direct suppliers servicing prime contractors. One respondent explained how this change was affecting his organization which had previously been just a subcontractor,

“...firms like M. are increasingly moving towards an integrator role, sourcing at least some of their output from outside, mainly low technology output that can be outsourced to paces like Asia. Instead M. can then concentrate on high technology outputs. This means that at $M$. we now manage somebody else doing something. We're doing an exercise now to seek outside people who can do work for us." 
The benefits of this type of arrangement, as far as prime contractors are concerned, were explained by a respondent from one of the larger suppliers when he explained that,

"This releases the aircraft constructor of the task of having to coordinate a large number of suppliers who contribute to the system at that level."

New style co-partnership relationships

The third aspect of lean supply is a move away from purely contractual relations in favour of greater emphasis on collaboration and partnership (Lamming, 1996, p184). Hislop (1997: p6) mentions changes in supplier relations as a feature of the aerospace industry in the 1990s and the same point was made by two of the key informants, one of whom described, 'new style supply arrangements' being adopted. Respondents from the industry were more specific. One respondent, who worked for a subcontractor, commented, 'our major customer has changed the way they deal with us', while another described, 'a move away from build-to-print'.

Build-to-print describes the traditional arrangement between contractor and subcontractor where the subcontractor performs processing operations to a specification laid down by the subcontractor. As one respondent put it, 'it was .... a case of taking a tape or program direct from the builder and just putting it in the machines'. Sometimes described as 'arm's length contracting' (Syson, 1992: p93), it requires nothing more than processing from the subcontractor. The five respondents who worked for subcontractors all described how their organizations were increasingly expected to do more than carry out processing operations. Typically the new arrangements involved the subcontractor 'using its expertise and experience to initiate improvements' in terms of manufacturing operations. A respondent working for a subcontractor described his organisation's input to these new working arrangements,

'There is a new design...and a lot of the drawings we get through are not final release, so there is a degree of working between ourselves and the design team to actually look at the engineering. We've certainly got involved in looking at actual products, approving them from the machining point of view.'

This closer collaboration was described by one key informant as, 'more use of partnerships and alliances than there was in the past', while a respondent employed by a prime contractor stated, 'there is increasing emphasis on working together with organizations up and down the supply chain'. This was echoed by a supplier who noted, 'They (the primes) are encouraging the supply chain to re-group and make itself more a partner than a contributor'.

Of course partnership can take very different forms. Lamming (1993, p180) talks about 'stronger vertical relationships' and 'very close ties'. One manifestation of a move away from conventional contracting in favour of partnership is the increased use of long term agreements. These are supply agreements of five or even ten years duration. The basic idea behind long term agreements as one practitioner explained is, 
'to allow the tier one supplier to schedule production for some time ahead in order to manage procurement and in turn have an organised and disciplined supply chain'.

Sometimes these agreements involve an increased level of business (coming from firms that do not sign up to such agreements) in return for price reductions.

However while several respondents referred to such agreements, many seemed to think that they represented an unequal form of partnership. Comments ranged from,

'Long term agreements are a joke. They are a response to a changing relationship in terms of the buyer/seller balance of power.'

and,

'they are adversarial, they like to talk about partnering and this, but there is a very strong us and them as far as customer supplier relationships.'

to,

'the term partnership is a little bit of a loose term. It is certainly not an equal partnership. There is some form of partnership but it is very much dominated by the customer at the end of the day.'

Hence while clearly relationships between customers and suppliers are changing and there is increasingly a two way flow of advice and guidance, equality of partnership as espoused by Lamming has not occurred.

\section{IMPLICATIONS FOR INNOVATION}

What are the implications for innovation? Does the evidence point to Lamming' s more optimistic view that under lean supply as one moves away from standardization and vertical integration there will be more scope for suppliers to innovate or does it point to Bruce and Moger' s more pessimistic view that the pressure to manage the supply chain efficiently will leave no time or scope for innovation? Given these opposing views, the implications for innovation of the strategic changes in the aerospace supply chain , especially whether suppliers are more or less active in relation to innovation, is a feature lean supply that provokes considerable interest. Initially the evidence favoured Bruce and Moger's perspective. Several respondents, when asked about the extent to which they were involved in innovation, stated categorically that their organization did not engage in innovation. They cited the lack of new projects in the civil aerospace field as the reason for this. Interestingly the same respondents at a later stage then proceeded to describe how their organizations had been active in introducing significant manufacturing process innovations.

Two examples stand out. Both were from suppliers who in the past might have been described as 'subcontract metal cutters'. The first was a new process for manufacturing large turbine blades or airfoils that form part of the compressor on a commercial jet engine. Given the demanding conditions under which they operate, the 
larger airfoils have traditionally been manufactured using forgings. However forging is a relatively slow process requiring highly skilled labour, that another respondent noted was often in short supply. The respondent described how his organisation had developed a technique for making large airfoils using the single crystal casting process (Prencipe, 1997: p1271) used for manufacturing small airfoils whereby a single grain is allowed to grow into the main body of the casting so as to avoid the boundaries between grains of metal that so often cause fatigue. This was no copycat innovation. Cooling is a key feature of the process for casting small airfoils. The increased amount of metal involved in casting large airfoils gives rising to further cooling problems. The company had, through much R \& D effort, developed a novel solution. As a result not only was it now possible to cast large airfoils instead of forging them, but it was possible to cast eight large airfoils at a time. Though not yet in production, the technique had enormous commercial potential. Hence the process was described as,

'a real 'A' rated technical process that no one else can copy and also one that is very commercially attractive, because you get a very big, high technology airfoil, but quickly.'

In a similar manner, another respondent, this time from a smaller supplier, described a process innovation his organization had undertaken. The company was involved in precision machining of components and the respondent described how,

'a lot of them [components] were made out of forgings and castings and as machining technologies improved there was the opportunity to manufacture from bar instead of forgings which is obviously cheaper and quicker. That again has probably been the biggest innovation we've done.'

These two cases show suppliers working more closely with their customers than would be the case with traditional build-to-print arrangements. However the cases also make clear that the absorptive capacity (Cohen and Levinthal, 1990) of each company was undiminished. Both companies were well aware of wider, external developments in their respective technologies and had the internal capacity both to assimilate such developments and make use of them in successfully pursuing process innovations. The companies may not have been active in product innovations, but the evidence presented here shows that both were active in terms of process innovations.

\section{CONCLUSION}

Earlier studies have pointed to significant changes within the aerospace industry in response to the new environment that emerged in the 1990s. A number of studies had extended this analysis to show the changes filtering down the supply chain both in the US and Europe. This study has plugged a gap by analyzing developments in the European country with the largest aerospace industry, namely the UK. Like earlier studies this too points to extensive re-structuring of the supply chain. 
However most earlier studies have been confined to analyzing the impact of changes in the aerospace environment. Only Giunta (2000) pointed to lean ideas as a powerful influence on the changes taking place and she reported only limited evidence of its influence within the aerospace supply chain in the Campania region of Southern Italy.

In contrast this study indicates that in the UK aerospace industry supply chain restructuring has been and continues to be extensive and there is strong evidence from across the supply chain of the influence of lean ideas. In particular the study points to major changes in the role of suppliers very much along the lines indicated by Lamming, who suggests that lean ideas should lead to significant changes in the role of suppliers hence his 'talented' suppliers. The only aspect of Lamming's talented suppliers not in evidence in the UK aerospace industry was the notion of their being on equal terms with their customers. Rather the study points to the balance of power remaining firmly with customers.

While it is tempting to suggest that aerospace is simply copying ideas from the automotive industry, closer examination of the industry context suggests the changes in the aerospace supply chain do not represent mimetic change as ideas and practices from the automotive sector percolate through to the aerospace industry. Such an analysis while quite plausible is much too simplistic. As the aerospace industry matures it is increasingly important for the prime contractors to utilize developments across a range of technologies. Under these circumstances systems integration becomes vitally important. Consequently the changes in the supply chain are largely organisational precisely because they are designed to make systems integration easier and more effective. This study has gone some way to identify and understand these organisational changes. However if we are to fully understand and account for these organisational changes in general and the emergence of strategic suppliers in particular, further detailed work is required following up these earlier findings.

In terms of innovation, Bruce and Moger's pessimistic predictions do not appear to be borne out. Nor for that matter was Lamming's optimistic scenario involving changes in the dynamics of innovation much in evidence, probably because his analysis was based on the automotive industry. Since standardization and mass production have never been a feature of aerospace, lean supply was never likely to lead to new innovation dynamics in this industry. However the study does show that talented suppliers are likely to be active in innovation, though in aerospace it appears more likely that this will be process, rather than product innovation, reflecting increased capability and competence. 
Djs/TALENTED SUPPLIERSv1.3/28 May 2003

\section{REFERENCES}

Bilstein, R.E. (2001) The Enterprise of Flight: The American Aviation and Aerospace Industry, Smithsonian Institution Press, Washington.

Bishop, P. and Williams, T. (1997) Restructuring the UK Defence Industry: Market Pressures and Management Initiatives, Long Range Planning, 30(1) pp21-28.

Bozdogan, K., Deyst, J., Hoult, D. and Lucas, M. (1998) Architectural innovation in product development through early supplier integration, $R \& D$ Management, 28 (3) pp163-173.

Brown, R. (2000) Clusters, Supply Chains and Local Embeddedness in Fyrstad, European Urban and Regional Studies, 7 (4) pp291-305.

Bruce, M. and Moger, S. (1999) Dangerous Liaisons: An Application of Supply Chain Modelling for Studying Innovations within the UK Clothing Industry, Technology Analysis and Strategic Management, 11(1) pp113-125.

Cohen, W.M. and Levinthal, D.A. (1990) Absorptive Capacity: A New Perspective on Learning and Innovation, Administrative Science Quarterly, 35, pp128-152.

Dent, C.A. and Klein, J.A. (1995) Technology management: the aero engine supply chain, in A. Demaid and J.H.W. De Wit (eds.) Case Studies in Manufacturing and Advanced Materials, Volume 2, Elsevier.

Dogannis, R. (2001) The airline business in the $21^{\text {st }}$ century, Routledge.

Francillon, R. (1998) Rampant Phoenix: UK aerospace resurgence through globalisation, Air International, 55(3) pp146-153.

Frear, C.R. and Metcalf, L.E. (1995) Strategic Alliances and Technology Networks: A Study of a Cast-Products Supplier in the Aircraft Industry, International Marketing Management, 24 pp379-390.

Freeman, C. (1991) Networks of innovators: a synthesis of research issues, Research Policy 20 pp499-515.

Gillham, B. (2000) Case Study Research Methods, Continuum, London.

Giunta, A. (2000) Large Firms and Subcontracting Relations in the Commercial Aircraft Industry: A Case Study of Campania in Southern Italy, in Giunta. A., Lagendijk, A. and Pike, A. (eds.) Restructuring Industry and Regions: The Experience of Europe's Regions, The Stationery Office, pp37-56. 
Djs/TALENTED SUPPLIERSv1.3/28 May 2003

Gray, M., Golob, E. and Markusen, A. (1996) Big Firms, Long Arms, Wide Shoulders: The 'Hub and Spoke' Industrial District in the Seattle Region, Regional Studies, 30(7) pp651-666.

Hanlon, P. (1999) Global Airlines: Competition in a transnational industry, $2^{\text {nd }}$ edition, Butterworth-Heinemann, Oxford.

Hayward, K. (1994) The World Aerospace Industry, Croom Helm.

Heppenheimer, T.A. (1995) Turbulent Skies: The History of Commercial Aviation, John Wiley and Sons, Chichester.

Hislop, D. (1997) Capabilities, Strategy and Environment: The Adaption of the UK Military Aircraft Industry to the Post-Cold War Environment, Technology Analysis and Strategic Management, 9(1) pp3-18.

Hobday, M. (1998) Product complexity, innovation and industrial organization, Research Policy, 26(6) pp689-710.

House of Commons (1993) British Aerospace Industry, Report of the Trade and Industry Committee, HMSO.

Kay, J. (1993) The Foundations of Corporate Success: How Corporate Strategies Add Value, Oxford University Press, Oxford.

Krafcik, J.F. (1988) Triumph of the Lean Production System, Sloan Management Review, Fall 1988, pp41-52.

Lamming, R. (1993) Beyond Partnership: Strategies for Innovation and Lean Supply, Prentice Hall.

Lamming, R. (1996) Squaring lean supply with supply chain management, International Journal of Operations and Production Management, 16(2), pp183-196.

Miles, M.B. and Huberman, A.M. (1994) Qualitative Data Analysis, $2^{\text {nd }}$ edition, Sage Publications.

Moore, D.M., Neal, D.J. and Antill, P.D. (2001) Supply Chain Management in SMEs within the defence aerospace industry - A case of simplification or increased complexity? International Journal of Aerospace Management, 1 (1) pp35-45.

Owen, G. (1999) From Empire to Europe: The Decline and Revival of British Industry Since the Second World War, Harper Collins

Paliwoda, S. J. and Bonaccorsi, A.J. (1994) Trends in Procurement Strategies within the European Aircraft Industry, Industrial Marketing Management, 23, pp236-244. 
Djs/TALENTED SUPPLIERSv1.3/28 May 2003

Pattillo, D. (1998) Pushing the Envelope: The American Aircraft Industry, University of Michigan Press, Ann Arbor.

Prencipe, A. (1997) Technological competencies and product's evolutionary dynamics: a case study from the aero engine industry, Research Policy, 25, pp1261-1276

Sako, M. (1994) Supplier Relationships and Innovation, in Dodgson, M. and Rothwell, R. (eds.) The Handbook of Innovation, Edward Elgar, Cheltenham, pp 268-292.

Sampson, A. (1984) Empires of the Sky: The Politics, Contests and Cartels of the World's Airlines, Random House, New York.

SBAC (2002) UK Aerospace Statistics 2001, Society of British Aerospace Companies.

Saunders, M. (1997) Strategic Purchasing and Supply Chain Management, $2^{\text {nd }}$ edition, Pitman Publishing.

Saunders, M., Lewis, P. and Thornhill, A. (2003) Research Methods for Business Students, $3^{\text {rd }}$ edition, FT Prentice Hall, Harlow.

Syson, A.R. (1992) Improving Purchasing Performance, Pitman.

Syson, A.R. (1989) The revolution in purchase, Purchasing and Supply Management, September 1989, pp16-21.

Talbot, D. (2002) Institutional Dynamics and Localised Inter-Firm Relations: The Case of Aerospatiale and its Subcontractors in Toulouse, European Urban and Regional Studies, 7 (3) pp223-236.

Todd, D. and Simpson, J. (1986) The World Aerospace Industry, Croom Helm.

Womack, J.P., Jones, D.T. and Roos, D. (1990) The Machine that Changed the World, Rawson Associates, New York.

Djs/Talented Suppliersv1.3/30 May 2003 